\title{
Challenges Facing Small and Medium Water Service Providers in Kenya: A Case of Amatsi Water Services Company, Vihiga County
}

\author{
Edwin K. Kanda \\ Department of Civil and Structural Engineering, Masinde Muliro University of Science and Technology, Kakamega, KENYA \\ ekanda@mmust.ac.ke \\ James Odiero \\ Amatsi Water Services Company, Kakamega, KENYA \\ jmodiero@yahoo.com \\ Valery O. Lutta \\ Department of Civil and Structural Engineering, Masinde Muliro University of Science and Technology, Kakamega, KENYA \\ vlutta@mmust.ac.ke \\ Basil T.I Ong'or \\ Department of Civil and Structural Engineering, Masinde Muliro University of Science and Technology, Kakamega, KENYA \\ bongor@mmust.ac.ke
}

\begin{abstract}
The access to water services is a fundamental human right. Water and sanitation services coverage in Kenya is low even with the implementation of reforms in the sector initiated in 2002. Small and medium Water Service Providers (WSP) face numerous challenges which are stifling their ability to sustainably fulfill their mandates without relying on subsidies from state or non-state entities. The aim of this study was to analyze the challenges facing water utilities in rural Counties using Amatsi Water Services Company as a case study. The performance of the WSP was analyzed for 2014 to 2017 and the challenges as depicted were classified into technical and economic parameters. The legal framework was also examined and its possible influence on the operation of the WSP. The main problems affecting small and medium WSPs include high non-revenue water, low metering of connections, low revenue collection efficiency, high operation and maintenance costs, governance challenges, insufficient funding and low quality of service. Furthermore, it is important for legislative clarity on the relationship among the institutions created by the Water Act 2016.
\end{abstract}

Keywords: Legal framework, Non-revenue water, Sanitation, Water service regulation, Water Supply

\section{INTRODUCTION}

Water and sanitation services are universal human rights. Therefore, countries aim at ensuring that their citizens gain access to water in sufficient quality and quantity. The states also strive to provide the best possible sanitation service. However, the access to water and sanitation service is still a challenge in most African countries. African countries have experienced rapid growth in population and increased urbanization. These coupled with inadequate funds for expansion of water and sanitation infrastructure leave majority of African citizens unable to access improved water and sanitation services. World Health Organization (WHO) and United Nations Children's Fund (UNICEF) 2014 report indicated that $40 \%$ of people without access to improved drinking water live in Africa (WHO \& UNICEF, 2014). Although globally the Millennium Development Goal (MDG) of halving the number of people without access to safe drinking water was met,
sub-Saharan Africa (SSA) did not meet its target (WHO \& UNICEF, 2015).

Sanitation services are low with unhealthy sanitation practices such as open defecation still practiced in some countries. In Africa, Northern African countries met the MDG on sanitation by 2010 and have since surpassed it with the other regions, notably Eastern, Western and Central Africa trailing far behind (Hickling, 2014). By 2012, SSA had made little progress with only $30 \%$ of the populace having improved sanitation services (WHO \& UNICEF, 2014). Out of the 1 billion people who practice open defecation, a large majority live in South Asia and SSA with around $66 \%$ of them in India (Howard et. al., 2016). Approximately $20 \%$ of people in Africa practice open defecation with Western Africa contributing 39\%, Eastern Africa, 34\% and Southern Africa, 16\% (Hickling, 2014).

The provision of water and sanitation services in most Counties in Kenya is faced with a myriad of challenges 
which vary spatially across the country. In 2015, the national water coverage was 55\% and sanitation stood at $15 \%$ (WASREB, 2016). The key to achieving universal access to water and sanitation as envisaged in Vision 2030 lies with the ability of water service providers (WSP) and their partners to rehabilitate the existing water infrastructure and expand to other uncovered areas, most notably the rural poor.

The statistics provided by the Ministry of Health $(\mathrm{MOH})$ of Kenya through water and sanitation program (WSP) indicate that, in 2014, 39.3\% of residents in Vihiga County had access to improved sanitation facilities and that the county loses around 307 million Kenyan shillings due to poor sanitation (MOH, 2014). The onus to the improvement of sanitation access to residents of Vihiga County rests in the County Government through the WSP and other community organizations with support from the national government, donors and the private sector. However, according to the Institute of Certified Public Accountants of Kenya (ICPAK), Vihiga County did not prioritize water and sanitation provision in the 2013/2014 financial year (ICPAK, 2014). It was, therefore, not surprising that the County was ranked the last in 2015 sector report with water coverage at 15\% and $0 \%$ in sewerage coverage (WASREB, 2015).

This paper discusses the challenges of the provision of water and sanitation service by small and medium water utilities particularly in rural counties using a case study of Amatsi Water services Company (AWASCO). AWASCO was licensed by Lake Victoria North Water Services Board (LVNWSB), in line with the water reforms initiated in the Water Act, 2002, to operate and maintain Maseno, Mbale, Kaimosi, Sosiani and Vihiga water supplies previously managed by the Ministry of Water and Irrigation (MWI). According to WASREB reports, $55 \%$ of the population in Vihiga County is within the service area of AWASCO (WASREB, 2015). The size classification of WSPs is based on the number of registered users as follows; less than 5,000, 5,000 $9,999,10,000$ - 34,999, and greater than 35,000 connections as small, medium, large and very large respectively (WASREB, 2016). Being a medium WSP (total connections of 8,087 in July 2017), AWASCO faces challenges in fulfilling its mandate as per the service provision agreement it signed with LVNWSB and thereby contributes to a large extent the low access of water and sanitation services in Vihiga County. Therefore, challenges analyzed in this paper would help in formulating policy and technical intervention in the water sector especially for small and medium WSPs which operate in rural Counties and whose populace is largely poor.

\section{METHODOLOGY}

The study involved analyzing the performance of AWASCO in 2014/2015 to 2016/2017 financial years. The data was collected from secondary sources which were the company records. The data collected was the number of customers connected to the pipe network of the company, active customers, the dormant connections, metering ratio, the revenue generated, the expenses for the three years and the number of staff employed. The company's performance was compared to the standards set by the regulator.

The status of water supply infrastructure was also assessed in terms of volumes of water produced, its operation and maintenance procedures, and whether they operate optimally. The water infrastructure such as the distribution network and storage reservoirs influence the physical losses due to leaks and bursts. Use of faulty meters also contributes to the poor accounting of water produced and/ or sold.

The operating legal framework was examined and its influence on the company's performance. The main documents considered were the Water Act (2002) and its successor the Water Act (2016) and the Water (Services Regulatory) Rules (2012). From the performance, the problems facing the firm was categorized into technical, economic and legal challenges.

\section{RESULTS AND DISCUSSION}

\subsection{Technical Challenges}

The technical challenges are those related to the water supply infrastructure which limits the capability of the WSP to deliver services to residents. The technical challenges could be inherent in the company's internal operating environment or enforced from the external environment emanating from the company's location.

\subsubsection{Water resource availability and production capacity}

The challenges facing water utilities emanate from the availability and reliability of the sources of water for treatment and distribution to consumers. The source of water (supply) should meet the long-term demand projections besides being relatively unpolluted to minimize the cost of treatment.

The sources of water for AWASCO include both surface and groundwater. Mbale water supply scheme receives its water from R. Idigoi; a tributary of $\mathrm{R}$. Edzava while Maseno water supply scheme receives from R. Zaaba. Kaimosi water supply scheme, on the other hand, obtains its water from Kaimosi dam. Sosiani and Vihiga schemes use protected springs as their 
sources of water. These existing groundwater sources pose challenges to the water utility since they cannot be expanded to meet the increasing water demand. Therefore, there is a need for the development of alternative water sources to cater for residents in Sosiani and Vihiga areas.

The design and the production capacities for the four schemes are indicated in Table 1.

Table 1. Production efficiency of AWASCO water schemes

\begin{tabular}{llll}
\hline Scheme & $\begin{array}{l}\text { Design } \\
\text { Capacity } \\
\left(\mathrm{m}^{3} / \text { day }\right)\end{array}$ & $\begin{array}{l}\text { Production } \\
\text { Capacity } \\
(\%)\end{array}$ & $\begin{array}{l}\text { Water } \\
\text { Source }\end{array}$ \\
\hline Mbale & 2,300 & 56.5 & Surface \\
Maseno & 2,400 & 62.5 & Surface \\
Kaimosi & 1,440 & 69.4 & Surface \\
Vihiga & 150 & 93.3 & Ground \\
Sosiani & 400 & 100 & Ground \\
\hline
\end{tabular}

Mbale water supply system (distribution, treatment and associated works) has been rehabilitated and currently, the scheme is able to produce $3,000 \mathrm{~m}^{3} /$ day (LVNWSB, 2017). From Table 1, Maseno and Kaimosi plants are operating below their design capacities due to old infrastructure which requires rehabilitation. There is also room for expansion of the two schemes since their design capacities are 19\% (Maseno) and 17\% (Kaimosi) of the allocated abstraction rights granted by the Water Resources Management Authority (WRMA). There is no room for expansion of Sosiani scheme since the design capacity is equivalent to the abstraction rights of the spring. However, there is a need for expansion of Vihiga water production plant because the design capacity is $37.5 \%$ of the total water abstraction rights for the spring.

The average daily water production in AWASCO for the three years is shown in Figure 1. The average production ranged from $3,019 \mathrm{~m}^{3} /$ day to $4,629 \mathrm{~m}^{3} /$ day with an average of $4,100 \mathrm{~m}^{3} /$ day, $3,892 \mathrm{~m}^{3} /$ day, 4,234 $\mathrm{m}^{3} /$ day for 2014/2015, 2015/2016 and 2016/2017 respectively.

From Figure 1, the average daily production was lowest in $2015 / 2016$. This was attributed to intermittent power supply due to non-payment of power bills and the failure of one of the filtration units at Maseno water treatment plant.

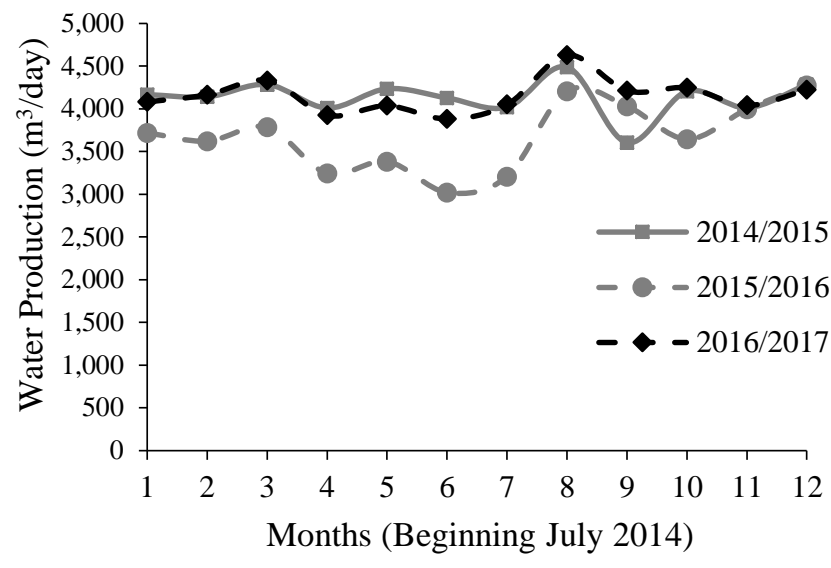

Figure 1. Water production

\subsubsection{Quality of service}

This is measured by the water coverage, drinking water quality compliance and the hours of water supply (WASREB, 2016). The water company should, in ideal situations, supply water for 24 hours in a day. The average duration in which AWASCO supplied water to the residents was 16.6 hours which is above the acceptable water sector minimum of 16 hours as shown in Figure 2.

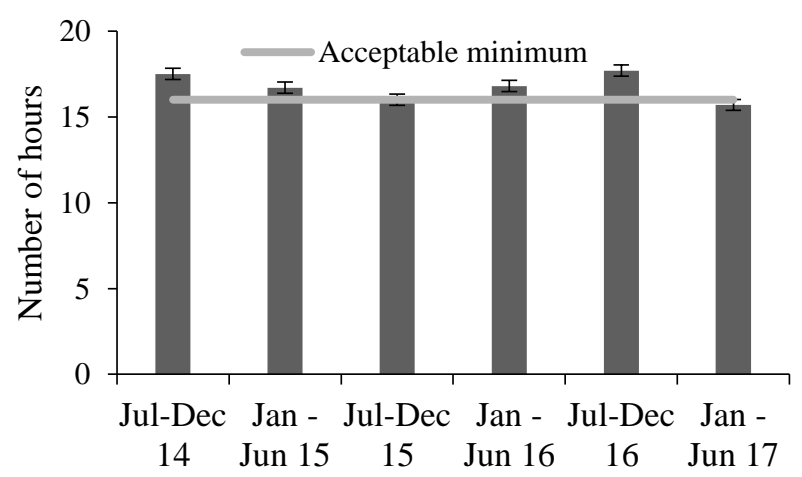

Figure 2. Average water supply hours in AWASCO

The population in the service area of AWASCO increased by $12.9 \%$ from 2014 to 302,400 in 2017 . The percentage of people receiving the water service from the water utility increased from $34 \%$ to $45.5 \%$ in the same duration. Although this is an improvement of more than $10 \%$, it falls far below both the acceptable sector benchmark of above $80 \%$ set by the Water Services Regulatory Board (WASREB) and the national average of 55\% (WASREB, 2016). Perhaps AWASCO can improve its service coverage by servicing the dormant connections which stand at an average of $63.9 \%$. The low water coverage and existence of high percentage of dormant connections signals that the utility is not capable of supplying the service or the quality of service is poor making the dissatisfied consumers discontinue their reliance on the company 
services. This has an overall effect of reducing the revenues generated by the water utility and thereby declining sustainability in the long run.

The quality of water supplied by the company should meet the guidelines provided by the Kenya Bureau of Standards (KEBS) and enforced by WASREB and LVNWSB. The water utility is required by WASREB to comply with the examination of residual chlorine levels and bacteriological tests. AWASCO recorded an average of $95.3 \%$ compliance in 2014 - 2017 which was above the minimum acceptable benchmark of $90 \%$. Indeed, a study by LVNWSB on the quality of water at AWASCO confirmed that it meets the physical, chemical, and bacteriological standards, and thus safe for consumption (LVNWSB, 2016).

\subsubsection{Non-Revenue Water}

Non-Revenue Water (NRW) comprises the portion of water produced that is not billed. NRW should be differentiated with unaccounted for water (UFW). UFW excludes authorized consumption which is not billed and therefore do not form revenue stream of the water utility. The scope of NRW, as defined by International Water Association (IWA), is illustrated in Table 2.

Therefore, NRW was computed as in Equation (1). $N R W=\frac{\text { Total water produced }, m^{3}}{\text { Total water sold }(\text { billed }), m^{3}} \times 100$

The NRW for AWASCO during $2014-2017$ is illustrated in Figure 3. The NRW declined from 43.6\% in $2014 / 2015$ to $32.7 \%$ in 2016/2017 (Figure 3). Although the NRW follows a declining trend, it is still above the maximum WASREB sector benchmark of $25 \%$. The main factors contributing to high NRW levels in AWASCO are dilapidated and aged water distribution system and low metering. This makes the distribution system susceptible to leakages and bursts which contribute to physical water losses.

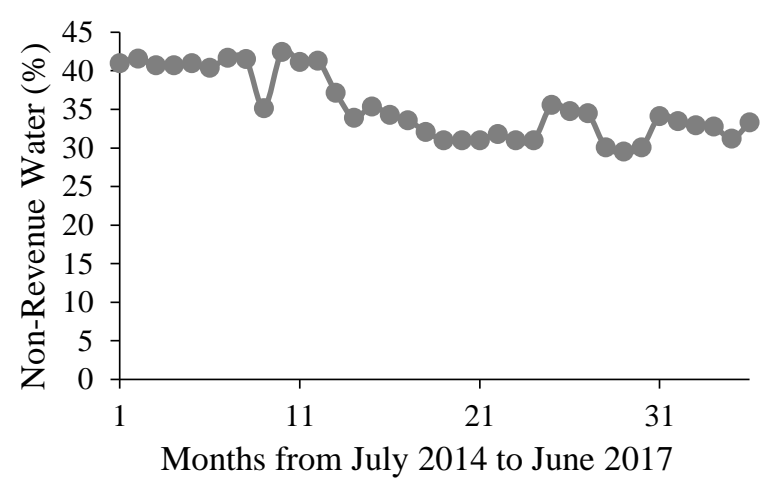

Figure 3. Non-Revenue water for Amatsi Water Services Company

Most of the connections are not metered with an average of $47 \%$ of the consumers being billed on flat rate charges. There was a significant positive relationship between NRW and the percentage of flat-rate connections $(p<0.05)$. This implies that the use of flatrate charges to bill consumers contributed to high NRW values. The use of flat rate in the pricing of water is a disincentive to water conservation. This means that consumers are enticed to use as much water as they can and consequently do not pay the full cost of the volume consumed. The principle of treating water as an economic good is thus negated in AWASCO with the flat rate water pricing model. It is also against the userpay principle (MWI, 2007). Globally, lack of incentives for management to reduce water losses, corruption, lack of awareness among users and lack of political will are the main reasons for high NRW in water utilities (González et. al., 2011)

Table 2. Revenue and Non-revenue water classification (Farley, 2003)

\begin{tabular}{|c|c|c|c|}
\hline \multirow{4}{*}{$\begin{array}{l}\text { Authorised } \\
\text { Consumption }\end{array}$} & Billed & Billed Metered Consumption & \multirow[b]{2}{*}{ Revenue Water } \\
\hline & $\begin{array}{l}\text { Authorised } \\
\text { Consumption }\end{array}$ & Billed Unmetered Consumption & \\
\hline & \multirow{2}{*}{$\begin{array}{l}\text { Unbilled } \\
\text { Authorised } \\
\text { Consumption }\end{array}$} & Unbilled Metered Consumption & \multirow{7}{*}{ Non-Revenue Water } \\
\hline & & Unbilled Unmetered Consumption & \\
\hline \multirow{5}{*}{$\begin{array}{l}\text { Water } \\
\text { Losses }\end{array}$} & \multirow[t]{2}{*}{ Apparent Losses } & Unauthorised Consumption & \\
\hline & & Customer Metering Inaccuracies & \\
\hline & \multirow[t]{3}{*}{ Real Losses } & Leakage on Transmission and/or Distribution Mains & \\
\hline & & Leakage and Overflows at Utility's Storage Tanks & \\
\hline & & $\begin{array}{l}\text { Leakage on Service Connections up to point of Customer } \\
\text { metering }\end{array}$ & \\
\hline
\end{tabular}




\subsubsection{Sanitation services}

AWASCO do not offer sanitation services. The company has not developed sewerage infrastructure. This is occasioned by the fact that the asset developer (LVNWSB) had not constructed sewerage systems for the area and therefore the company inherited water supply facilities only. This denies the consumers access to sanitation services and the water utility cannot generate revenue from the same. Also, the use of on-site sanitation methods such as pit latrines, septic tanks etc. by the residents may lead to pollution of water sources, especially the groundwater. This poses a serious public health concern. This may affect the company in terms of water treatment. Since the company does not own the sanitation facilities, they do not have control over their designs, operations, and maintenance. According to (Roche \& Obeng, 2014), although most countries have septic tank design guidelines and standards, they are not adhered to in most cases.

On a positive note, there are plans by LVNWSB to construct sewerage facilities in Chavakali, Luanda and Mbale urban towns.

\subsection{Economic Challenges}

Water supply infrastructure in Kenya requires substantial investments to realize the $100 \%$ accessibility of water as outlined in Vision 2030. More than half of financial investments in the water sector come from foreign donors (WASREB, 2015). WSPs aim at the full recovery of costs through internally generated revenue for them to be sustainable. The commercial viability of WSPs depends mostly on its ability to collect and manage the revenues generated from the water supplied. Additionally, they need to attract funding from commercial banks and other lending agencies to fund expansion projects.

Due to their size, small and medium WSPs are not attracting commercial lenders due to their inability to break even without government subsidy, and thus low creditworthiness. The low creditworthiness also limits the WSPs from accessing result based financing from the Water Sector Trust Fund (WSTF).

The economic challenges considered are the revenue collection efficiency and the operation and maintenance cost coverage.

\subsubsection{Revenue collection efficiency}

The revenue collection efficiency is the ratio of revenue collected to the total water billed. The revenue collection efficiency of AWASCO is illustrated in Figure 4 . The average for the 3 years stood at $75.5 \%$ which was below the sector benchmark of $85 \%$. This implies that the ability of the company to recover costs for its operations is somehow compromised. According to (Sambu \& Tarhule, 2013), the collection efficiency of WSP is an indicator of its financial strength to extend water coverage and a measure of customer satisfaction to the services offered via their willingness to pay. Low revenue collection efficiency by small and medium WSPs could be attributed the economies of scale where large WSP report up to four times staff productivity (number of collections per staff) to what is reported by those in the small category (WASREB, 2016).

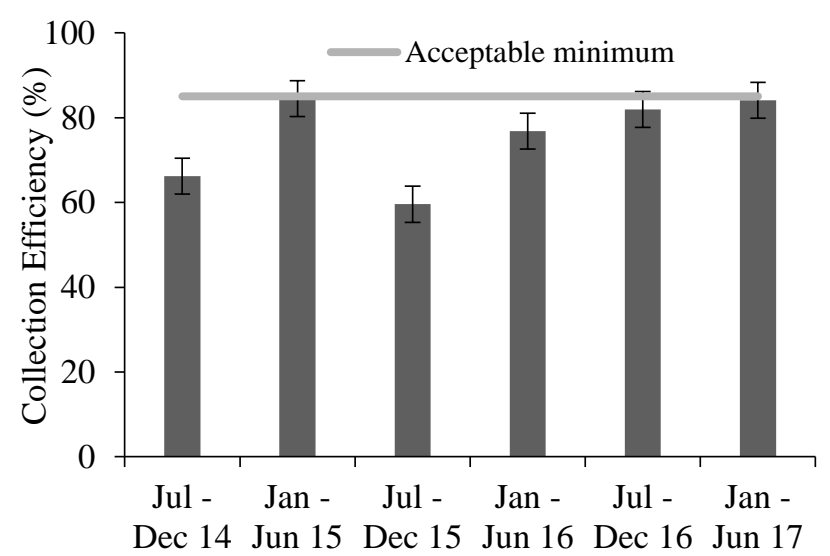

Figure 4. Revenue collection efficiency

Multiple regression analysis of revenue collected (dependent variable) with NRW and metered connections was carried out to determine which of the two variables influenced the firm's financial status. The results indicated that NRW had a negative and significant effect on revenue collected ( $p<0.05)$. The results further showed that metered connections had a positive influence on revenue collected, though it was insignificant $(p>0.05)$. The regression model had $R^{2}$ of 0.25 indicating that there are many other variables which influence the amount of revenue collected. This could include staff productivity and customers' willingness to pay (which is related to the quality of service and economic status). AWASCO recorded an average staff of 40 per connection for the 3-year period. Staff productivity measures the efficiency of WSPs in utilizing their staff. The regulator recommends a low Figure of $7-11$ for medium WSPs. Therefore, AWASCO is not utilizing its staff efficiently.

\subsubsection{Operation and maintenance cost recovery}

Sustainability of water utilities, in the short term, is pegged on their ability to fully cover operation and maintenance $(\mathrm{O} \& \mathrm{M})$ costs from the revenue generated internally through water sales. The $\mathrm{O} \& \mathrm{M}$ costs included personnel, chemical costs, energy, 
levies, fees, maintenance of infrastructure and other general expenditure such as allowances for Board of Directors. The ratio of revenue billed and $\mathrm{O} \& \mathrm{M}$ cost is an indicator of the extent to which the company can operate using internally generated funds. It is thus a measure of the financial sustainability. The revenue to O \& M ratio for AWASCO averaged $59.1 \%, 86.4 \%$, and $66.8 \%$ in $2014 / 15,2015 / 2016$ and 2016/2017 years (Figure 5). The results indicate that AWASCO performance on covering its $\mathrm{O} \& \mathrm{M}$ expenses from the revenue collected is below the sector benchmark of $100 \%$ set by the regulator. This implies that AWASCO cannot fund its operations without subsidies and thus the WSP has a long way in achieving sustainability.

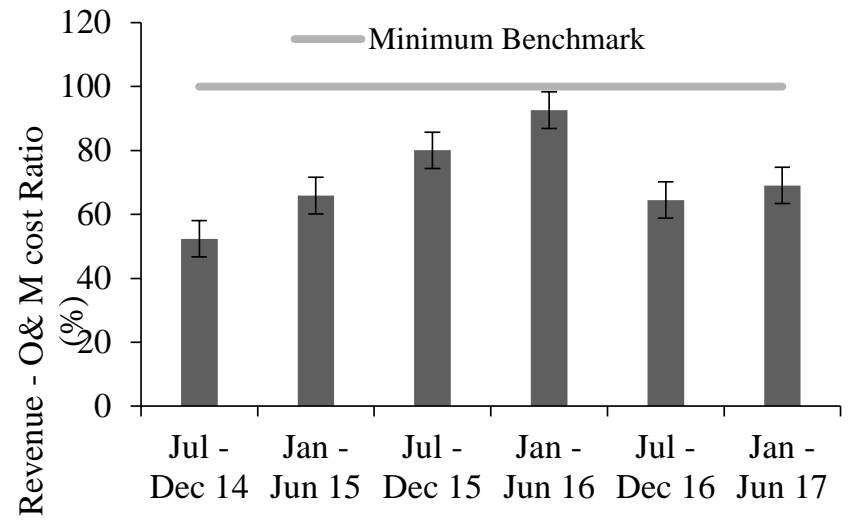

Figure 5. O\& M cost coverage

Energy and personnel costs constituted the largest and second largest components of $\mathrm{O} \& \mathrm{M}$ costs at $48 \%$ and $40 \%$ respectively (Figure 6). The sector benchmark provides that the personnel costs should be less than $30 \%$. Therefore, AWASCO is performing poorly in terms of personnel costs. The water utility can, therefore, reduce the $\mathrm{O} \& \mathrm{M}$ costs by leveraging on energy costs using gravity water distribution systems, optimal operation of pumping equipment, and utilization of green energy options such as solar. Rationalization of personnel costs is tricky for WSPs to navigate since it affects other parameters such as staff morale, productivity and attraction and retention of qualified/skilled staff which will ultimately affect the revenue collection efficiency and optimal operation of water infrastructure.

\subsection{Legal Challenges}

In addition to economic and technical challenges, WSPs also face problems which relate to the existing pieces of legislation and policies. These legal challenges affect the company's operating environment and in some circumstances, inhibit the realization of their goals and visions. The legal challenges are discussed with respect to the legal framework, governance and water pricing.

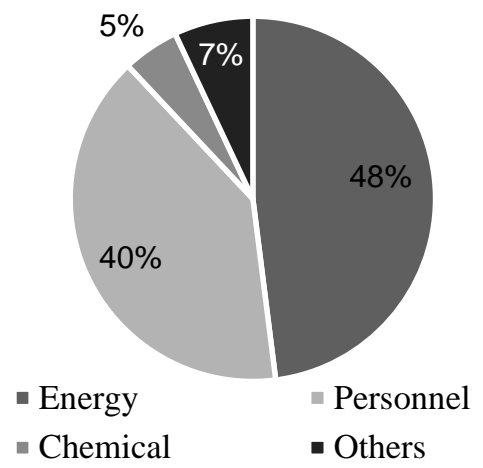

Figure 6. Components of $\mathrm{O} \& \mathrm{M}$ costs

\subsubsection{Legal framework}

The legal framework under which WSP operated was the Water Act 2002. The WSP was licensed by the Water Service Boards to provide water and sanitation services in a given area (GOK, 2002). However, with the enactment of the Constitution of Kenya, 2010, which created the devolved level of governments, the new Water Act 2016 was established to align the water sector with the devolved units. Water and sanitation services are the roles of the County governments. This implies that WSPs fall under the County Government in its area of jurisdiction. The Water Act, 2016 commencement date was $21^{\text {st }}$ April 2017. When the new Water Act, 2016 will be fully operational, Water Works Development Agencies (WWDA) will be responsible for the development of national water infrastructure assets such as dams and bulk water distribution systems. It will also be responsible for the management and operation of water and sanitation services until they are handed to the respective County governments or, joint County government committee (in cases where the assets are cutting across Counties (GOK, 2016).

WSP was licensed by water service boards (predecessor to WWDA when established) but now the Water Services Regulatory Authority (WASREB) is the sole body responsible for the licensing and registration of companies who wish to provide water and sanitation services. WWDA in principle operate across several counties and it follows hydrological units in areas of jurisdiction and they help in the development of water infrastructure. WSPs, on the other hand, are supposed to be semi-autonomous in operation; being under the County government whose constitutional mandate is water service provision to its residents. 


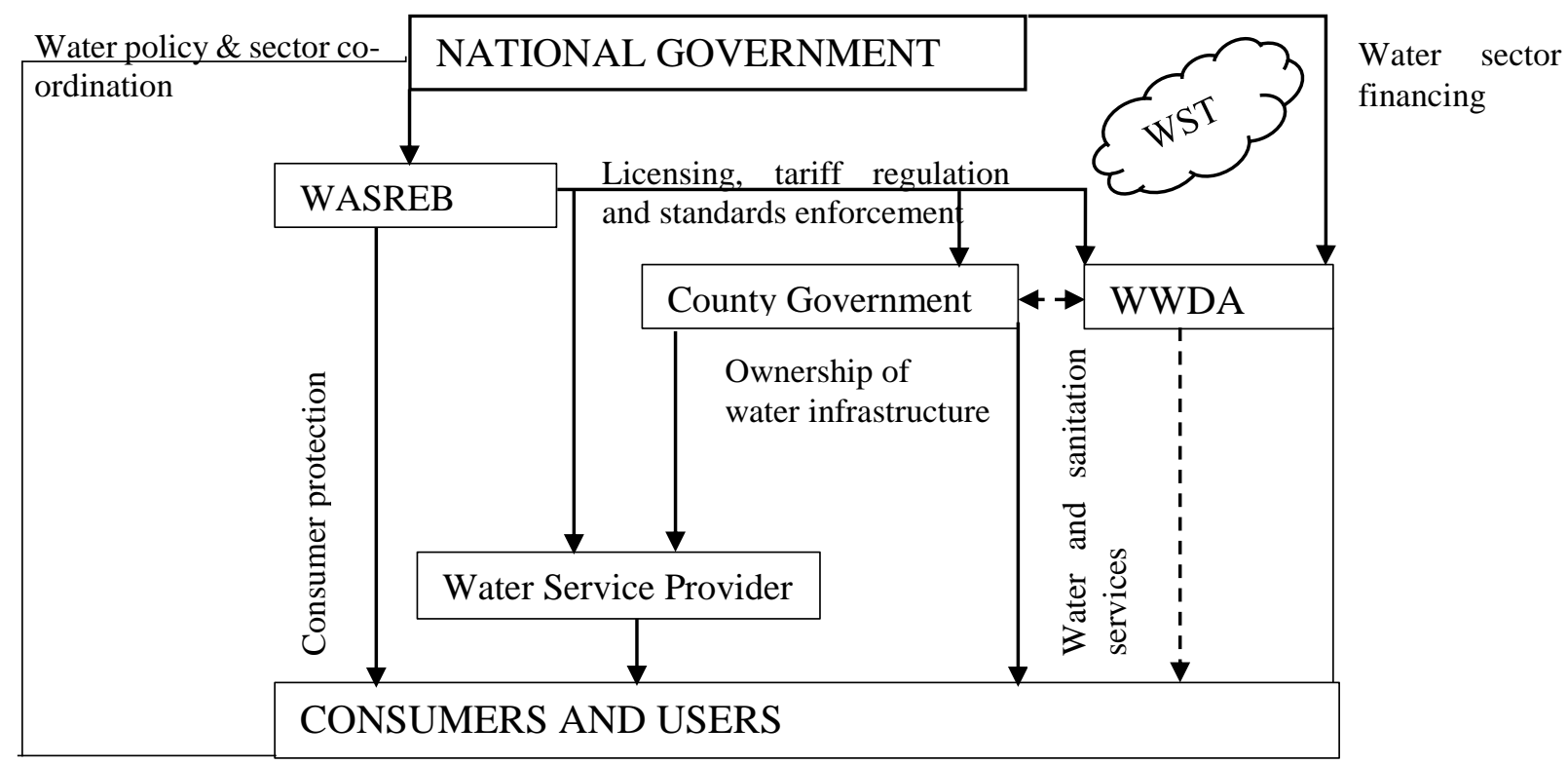

Figure 7. Relationship among institutions established for water and sanitation service provision N/B: This set-up excludes water resources management sub-sector

Figure 7 depicts the envisaged relationship among the institutions mandated to offer water and sanitation services. The County government, according to section 77 of the Water Act (2016), should establish WSP as a public limited company (GOK, 2016). The established WSP should apply for licensing from WASREB to authorize it to provide water and sanitation services in their areas of jurisdiction.

As depicted in Figure 7, there seems to be a potential conflict in terms of the role of county governments. Although WASREB grants the operational license to WSPs, the county governments do not have powers to oversight the latter in terms of operational performance. There is a need for clarity on how the County governments will monitor the performance of WSPs under their areas of coverage. The legislation at the County levels needs to provide for oversight mechanisms and the relationship between the County Government and WSPs on one hand and the County government and WASREB (being a national body and discharge functions of the national government) on the other hand. There is also need for clarity on how the WWDA provides water services in transition before handing to County Government vis-a-vis the role of Counties overseeing the same functions.

\subsubsection{Governance}

Although the WSP is expected to practice good governance, the influence of political environment existing in County governments cannot be wished away since the Water Act (2016) provides for cases of County-owned water utilities. (K'akumu \& Appida, 2006) reported that local authorities interfered in the running of the water utilities that they had incorporated. WASREB cite political interference as a threat to the management and activities of WSPs (WASREB, 2015). Corporatization of water and sanitation providers does not insulate them from political interference where local politicians circumvent formal rules to influence the appointment of the managers (Herrera \& Post, 2014). Separation of County affairs from the running of water utilities will allow County Assemblies to audit their performance (WASREB, 2016). WSPs should be given as much autonomy as possible in terms of operation and management to enable them to run on socio-business principles (water as both social and economic good).

\subsubsection{Water pricing}

Regulation of tariffs by WASREB protects consumers from exploitation by water utilities (Figure 7). This is good from the consumer perspective. However, small and medium WSPs or those serving in rural counties like AWASCO do not enjoy economies of scale or are riddled with internal inefficiencies and thus cannot be economically sustainable without subsidies from the County governments or other entities. The increasing block tariff structure is not sustainable for WSPs whose customer base is small and therefore cannot cross-subsidize the baseline tariff from the higher blocks.

Furthermore, the tariff review process is longer and therefore the tariffs are not regularly updated to reflect the changes in the macroeconomic environment (WASREB, 2015). According to the regulations, the period for review of tariffs in Kenya is 3 years (GOK, 
2012). As at 2014, AWASCO was operating on expired Extraordinary Tariff adjustment (ETA) as they waited for review and approval of Regular Tariff Adjustment (RTA).

A study by (Banerjee et. al., 2010) found that most African water utilities that use increasing block tariff can achieve full recovery of $O \& M$ costs at the higher blocks but not at the lifeline (lower block) tariff. This, therefore, may make small and medium WSP seek approval for higher tariffs from the regulator. Higher tariffs are counterproductive since it will price out the poor from the water service which impacts on revenue collection efficiency of the water utility and negate the gains on the road to the attainment of universal access to water services as outlined in Vision 2030.

According to (Wichelns, 2013), volume differentiated tariff has the potential for directing the subsidized rates to the poor households and exclude the richer from consuming water at the lifeline block rate whereas increasing block tariff does not exclude the rich from getting water in the lower block and thus the latter distorts the intention of the subsidy in the first place. It is, therefore, necessary for water regulators such as WASREB to assist WSPs develop and implement other alternative tariff models apart from the most common increasing block tariff model. (Wagah et. al., 2010) found a strong and significant positive correlation $\left(\mathrm{r}^{2}=0.99, \mathrm{p}<0.05\right)$ between household income and the volume of water consumed. This may lend credence to those advocating for the use of alternative tariff models to capture the economic zones or areas in water pricing. This will require the synchronization of the water laws with other legislation relating to urban and physical planning. However, discriminated water tariffs based on economic zones may pose administration difficulties to the WSP.

\section{CONCLUSIONS AND RECOMMENDATIONS}

The challenges facing small and medium WSP in Kenya using Amatsi Water Service Company in Vihiga County has been discussed. The main challenges facing small and medium WSPs are the high level of Non- Revenue Water which arose due to flat-rate connections, and leaks and bursts due to dilapidated water infrastructure, poor quality service in terms of water coverage, low revenue collection efficiency, and low financial sustainability because of low $\mathrm{O} \& \mathrm{M}$ coverage.

Political interference in the management of WSPs due to its affiliation directly or indirectly with the County Government is a potential problem. This is a threat to the operational independence of the WSPs as envisaged in the water sector reforms initiated in the last decade. There is a need for clarity on the existing legislation to shield the WSPs from interference from political quarters. Moreover, the roles of the institutions in the water and sanitation sector such as the WWDA, the County Government, WASREB and the WSP need to be clarified in the wider context of the legal framework.

Finally, the WSPs should improve their overall financial management including prudent internal controls aimed at improving revenue collections to attract funding from public and private commercial lenders for their expansion of water and sanitation infrastructure.

\section{REFERENCES}

Banerjee, S., Foster, V., Ying, Y. \& Skilling, H., 2010. Cost Recovery, Equity, and Efficiency in Water Tariffs: Evidence from African Utilities (WPS 5384). [Online]

Available

at:

https://openknowledge.worldbank.org/handle/10986/ $\underline{3868}$

Farley, M., 2003. Non-revenue water - international best practice for Assessment, monitoring, and control. Atlantis, 12th Annual CWWA Water, Wastewater \& Solid Waste Conference.

GOK, 2002. The Water Act. Nairobi: Government Printer.

GOK, 2012. The Water (Services Regulatory) Rules. Nairobi: Government Printer.

GOK, 2016. The Water Act. Nairobi: Government Printer.

González, F. G., García, M. A. R. \& Guardio, 2010. Why is non-revenue water so high in so many cities? Water Resources Development, 27(02), pp. 345-360.

Herrera, V. \& Post, A. E., 2014. Can developing countries both decentralize and depoliticize urban water services? Evaluating the legacy of the 1990s reform wave. World Development, Volume 64, pp. 621-641.

Hickling, S., 2014. Status of sanitation and hygiene in Africa. London: IWA Pblishing.

Howard, G., Calow, R., Macdonald, A. \& Bartram, J., 2016. Climate change and water and sanitation: likely impacts and emerging trends for action. Annual Review of Environment and Resources, Volume 41, pp. 253-276. 
ICPAK, 2014. A Baseline Survey on Devolution in Kenya with Respect to Public Financial Management Systems - One Year On. [Online] Available at: https://www.icpak.com/wp.../ICPAKDevolution-Baseline-Survey-Report-2014.pdf

K'akumu, O. \& Appida, P., 2006. Privatisation of urban water service provision: the Kenyan experiment. Water Policy, 8(4), pp. 313-324.

LVNWSB, 2016. Water Quality standards. Water and Beyond, 1212.

LVNWSB, 2017. List of Completed Projects Kakamega: Lake Victoria North Water Services Board.

[Online]

Available at:

http://www.lvnwsb.go.ke/index.php/projects/complet ed-projects/126-mbale-water-supply

MOH, 2014. County Sanitation Profiles: State of Sanitation in Vihiga County. Nairobi: Ministry of Health.

[Online]

Available at:

http://devolutionhub.or.ke/file/8df8ba22dac35f96ee6

54d1109a3d101.pdf

MWI, 2007. The National Water Services Strategy, 2007 - 2015. Nairobi: Ministry of Water and Irrigation.

[Online]

Available at: https://wasreb.go.ke/national-waterservices-strategy.

Roche, R. \& Obeng, L. A., 2014. Sanitation services in towns. In: P. Cross \& Y. Coombes, eds. Sanitation and Hygiene in Africa. London: IWA Publishing, pp. 143-149.

Sambu, D. K. \& Tarhule, A., 2013. The progress of water service providers in meeting millennium development goals in Kenya. African Geographical Review, , 32(2), 105-124., 32(2), pp. 105-124.

Wagah, G. G., Onyango, G. M. \& Kibwage, J. K., 2010. Accessibility of water services in Kisumu municipality, Kenya. Journal of Geography and Regional Planning, 3(5), pp. 114 -125.

WASREB, 2015. Impact: A Performance Review of Kenya's Water Services Sector 2013 - 2014, Nairobi: Water Services Regulatory Board.

WASREB, 2016. Impact: A Performance Review of Kenya's Water Services Sector 2014 - 2015, Nairobi: Water Services Regulatory Board.

WHO \& UNICEF, 2014. Progress on drinking water and sanitation - 2014 update. Geneval New York: World Health Organization and United Nations Children's Fund. [Online] Available at: https://www.unicef.pt/progressossaneamento-agua-potavel/files/progress-onsanitation-drinking-water2015.pdf.

WHO \& UNICEF, 2015. Progress on sanitation and drinking water - 2015 update and MDG assessment. Geneval New York: World Health Organization and United Nations Children's Fund. [Online] Available at: http://files.unicef.org/publications/files/Progress_on_ Sanitation_and_Drinking_Water_2015_Update_pdf

Wichelns, D., 2013. Enhancing the performance of water prices and tariff structures in achieving socially desirable outcomes. International Journal of Water Resources Development, 29(3), pp. 310-326. 
[This page is intentionally left blank] 